\title{
Assessment of development effectiveness of solar energy in Russia
}

\author{
Aleksey Bataev ${ }^{1, *}$, Vitaly Potyarkin ${ }^{2}$ Antonina Glushkova ${ }^{3}$ and Dmitry Samorukov ${ }^{2}$ \\ ${ }^{1}$ Peter the Great St.Petersburg Polytechnic University, 195251 St. Petersburg, Russia \\ ${ }^{2}$ National Technology Initiative Center for Advanced Manufacturing Technologies based \\ on the Institute of Advanced Manufacturing Technologies of Peter the Great St. \\ Petersburg Polytechnic University Polytechnicheskaya, 29, St.Petersburg, 195251, Russia \\ ${ }^{3}$ Samara National Research University, 34, Moskovskoye shosse, Samara, 443086, Russia
}

\begin{abstract}
Non-renewable fossils are the main source of energy in modern conditions. This method of production and consumption of energy acts as one of the main anthropogenic factors that negatively impact the environment. Besides, limited energy reserves do not guarantee the sustainable development of world energy in the long term. The way out of this situation is using renewable energy sources (RES). Renewable energy sources are one of the promising and innovative areas of energy development. These energy sources allow moving to a new high-quality level of power supply and heat supply of the country and significantly improving the ecological state of settlements. The Russian Federation has all conditions for the implementation of such innovative projects aimed at using renewable energy sources. One of such promising projects is solar energy. The perspective of using solar energy is an almost inexhaustible resource, available everywhere, and also has another advantage - high environmental safety. Besides, solar energy is characterized by low indicators in terms of capital and operating costs, a lower cost of electricity compared to traditional energy as well. In this study, the perspectives for the development of solar energy in the Russian Federation are identified. The existing solar capacities in Russia are analyzed, the main developments of solar energy in the country are determined. A model for assessing the economic efficiency of floating power plants is proposed in this paper. These plants make it possible to provide electricity to entire settlements. Having been the study, conclusions are drawn about the prospects of using such power plants as sources of cheap energy and environmental compatibility.
\end{abstract}

Keywords: natural resource management, renewable energy, solar energy, sustainable development, environment, financial analysis, floating power plants, modeling, investment

*Corresponding author: bat_a68@mail.ru 


\section{Introduction}

The 2004 study of the International Energy Agency showed that the most promising direction for the Russian Federation could be considered the development of the grid RES market, as well as off-grid electricity supplies based on such sources of electricity. The areas' development in the electric power industry as geothermal energy, wind energy, biomass and energy of small hydropower plants has shown its perspectives in the countries of the Organization for Economic Cooperation and Development (OECD). This was facilitated by a significant reduction in the cost of electricity, which became possible as a result of the implementation of major projects in this area, the introduction of more efficient production methods, and technological improvements. Autonomous power supply based on renewable energy sources is extremely beneficial, because electricity suppliers decrease their costs due to the lack of power lines, which are not needed in this case. It should be noted that a significant number of the population lives in remote and hard-to-reach areas in the Russian Federation. This prevents them from using conventional sources of electricity. [1-3] Autonomous systems using traditional fuels are quite costly due to the high cost of both the fuel and its delivery. Therefore, renewable energy sources are the way out under these conditions.

\section{Materials and methods}

In this study, the method of investment assessment was applied. It is considered in the form of a dynamic process that takes place in time and subject sections. In the first section, tasks that provide the life cycle of innovative projects are examined. In the second one, solutions are directed to the investment sector securing funding for projects in different aspects are developed. These aspects primarily involve the technical base of the investment project, its social significance, and financial viability of the project, its environmental safety, organization of project management, and the sufficiency of performance indicators as well. On the basis of the proposed method, an investment project was assessed to create floating power plants in the Russian Federation. [1-2, 4-5]

\section{$3 \quad$ Results and discussion}

Production of electricity from renewable sources in Russia is only $0.2 \%$ and includes the following power: geothermal, wind, solar, micro hydro, tidal, biofuel. [6]

There are 7 large solar power plants (SPP) in the Russian Federation (Fig. 1): 


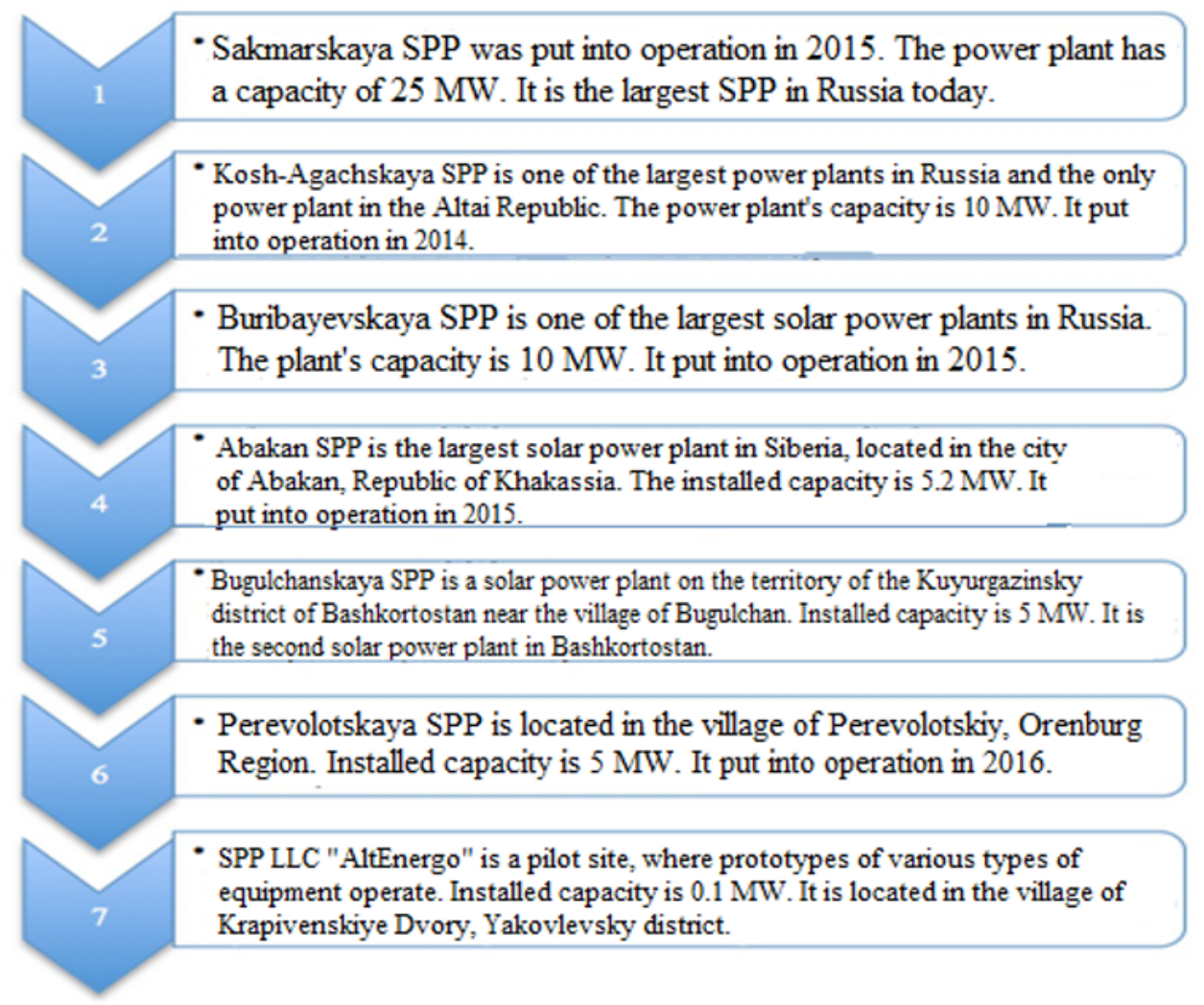

Figure 1. The largest solar power plants in Russia

The construction of solar power plants has led to a significant increase in installed capacity in the Russian Federation (Table 1).

Table 1. Growth rates of installed SPP capacities in Russia from 2014 to 2019

\begin{tabular}{|c|c|c|c|}
\hline Year & $\begin{array}{c}\text { Installed capacity by the end of } \\
\text { the year, MW }\end{array}$ & $\begin{array}{c}\text { Capacity growth } \\
\text { compared to the previous } \\
\text { year, MW }\end{array}$ & $\begin{array}{c}\text { Growth rate compared to } \\
\text { the previous year, \% }\end{array}$ \\
\hline 2014 & 295 & - & - \\
\hline 2015 & 300 & 5 & 1,7 \\
\hline 2016 & 320 & 20 & 6,7 \\
\hline 2017 & 360 & 40 & 12,5 \\
\hline 2018 & 529 & 169 & 46,9 \\
\hline 2019 & 829 & 300 & 56,7 \\
\hline
\end{tabular}

Solar power plants in Russia have actively been constructed for the last two years. [7] Despite the increase in the capacity of solar power plants in Russia, their share in the total volume of consumed electricity is very small, which indicates the need for further development of this area. One of the innovative projects in this area is the construction of floating solar power plants.

Floating solar power plants (FSPPs) becomes more and more popular due to their unique design and the lack of the need to allocate a plot of land for their placement. [8] Besides, such stations slow down the evaporation of water, which scientists consider an advantage for the environment. And the low temperature near the surface of the sea or 
ocean effectively cools the photovoltaic panels and reduces the risk of their failure. The initial data, which are given in Table 2, were used to evaluate the efficiency of investments in the construction of FSPP.

Table 2 Initial data

\begin{tabular}{|c|c|c|}
\hline & Measurement units & Value \\
\hline Year of construction start & year & 2019 \\
\hline Investment period & years & 25 \\
\hline Installed power $\left(\mathrm{N}_{\mathrm{y}}\right)$ & MW & 8 \\
\hline Total investment & thousand roubles & 722110 \\
\hline \multirow{3}{*}{ Discount rates } & roubles & \multicolumn{1}{|c|}{6} \\
\hline & \multirow{3}{*}{$\%$} & 8 \\
\hline & & 10 \\
\cline { 3 - 3 } & & 12 \\
\hline
\end{tabular}

The economic effect of building a floating solar power plant will be to generate "cheap" electricity. [9-11]

According to the FSPP project, its capacity will be $8 \mathrm{MW}$. According to experts, the cost of $1 \mathrm{~kW} \cdot \mathrm{h}$ of electricity from PSE is $1 \mathrm{ruble}$, and the amount of depreciation per unit of production is 0.8 rubles.

As can be seen from Table 2, the estimation is made according to four discount rates: $6 \%, 8 \%, 10 \%, 12 \%$. [12]

Further, one needs to evaluate the main indicators of the efficiency of the investment project (net present value, payback period, profitability index, and internal rate of return).

The calculation results are shown in Table 3. [13-16] When calculating, an annual growth of profit is taken in the amount of $7 \%$ due to an increase in energy prices.

Table 3 Net present value, thousand rubles

\begin{tabular}{|c|c|c|c|c|c|c|}
\hline $\begin{array}{c}\text { Years of the } \\
\text { investment project }\end{array}$ & Investments & $\begin{array}{c}\text { Net profit from } \\
\text { project } \\
\text { implementation }\end{array}$ & Cash flow & $\begin{array}{c}\text { Discount } \\
\text { rate (at a } \\
\text { discount } \\
\text { of } 6 \%)\end{array}$ & $\begin{array}{c}\text { Discounted } \\
\text { cash flow }\end{array}$ & $\begin{array}{c}\text { Cumulative } \\
\text { discounted } \\
\text { cash flow }\end{array}$ \\
\hline 1 & 2 & 3 & 4 & 5 & 6 & 7 \\
\hline 2019 & 722110 & 29580 & -692530 & 1 & -692530 & \\
\hline 2020 & & 31650,6 & 31650,6 & 0,943 & 29847 & -662683 \\
\hline 2021 & & 33866 & 33866,1 & 0,89 & 30141 & -632543 \\
\hline 2022 & & 36237 & 36236,8 & 0,84 & 30439 & -602104 \\
\hline 2023 & & 38773 & 38773,3 & 0,792 & 30708 & -571395 \\
\hline 2024 & & 41487 & 41487,5 & 0,705 & 29249 & -542147 \\
\hline 2025 & & 44392 & 44391,6 & 0,665 & 29520 & -512626 \\
\hline 2026 & & 47499 & 47499 & 0,642 & 30494 & -482132 \\
\hline 2027 & & 50824 & 50823,9 & 0,592 & 30088 & -452044 \\
\hline 2028 & & 54382 & 54381,6 & 0,558 & 30345 & -421699 \\
\hline 2029 & & 58188 & 58188,3 & 0,527 & 30665 & -391034 \\
\hline 2030 & & 62262 & 62261,5 & 0,497 & 30944 & -360090 \\
\hline 2031 & & 66620 & 66619,8 & 0,469 & 31245 & -328845 \\
\hline 2032 & & 71283 & 71283,2 & 0,442 & 31507 & -297338 \\
\hline 2033 & & 76273 & 76273 & 0,417 & 31806 & -265532 \\
\hline 2034 & & 81612 & 81612,2 & 0,394 & 32155 & -233377 \\
\hline 2035 & & 87325 & 87325 & 0,372 & 32485 & -200892 \\
\hline 2036 & & 93438 & 93437,8 & 0,361 & 33731 & -167161 \\
\hline 2037 & & 99978 & 99978,4 & 0,35 & 34992 & -132169 \\
\hline
\end{tabular}




\begin{tabular}{|c|c|c|c|c|c|c|}
\hline 2038 & & 106977 & 106977 & 0,33 & 35302 & -96866 \\
\hline 2039 & & 114465 & 114465 & 0,312 & 35713 & -61153 \\
\hline 2040 & & 122478 & 122478 & 0,299 & 36621 & -24532 \\
\hline 2041 & & 131051 & 131051 & 0,284 & 37219 & 12686 \\
\hline 2042 & & 140225 & 140225 & 0,275 & 38562 & 51248 \\
\hline 2043 & & 150041 & 150041 & 0,266 & 39911 & 91159 \\
\hline
\end{tabular}

Net present value becomes positive starting in 2041. Thus, the investment is suggested to be profitable. The total net present value for the entire period would amount to 91,159 thousand rubles.

Net discounted income was estimated similarly at various discount rates (Table 4).

Table 4. Net present value for various discount rates, thousand rubles

\begin{tabular}{|c|c|c|c|c|c|c|c|}
\hline $\begin{array}{c}\text { Years of the } \\
\text { investment } \\
\text { project }\end{array}$ & Cash flow & $\begin{array}{c}\text { Discount } \\
\text { rate ( 8\%) }\end{array}$ & $\begin{array}{c}\text { Discounted } \\
\text { cash flow }\end{array}$ & $\begin{array}{c}\text { Discount } \\
\text { rate }(10 \%)\end{array}$ & $\begin{array}{c}\text { Discounted } \\
\text { cash flow }\end{array}$ & $\begin{array}{c}\text { Discount } \\
\text { rate } \\
(12 \%)\end{array}$ & $\begin{array}{c}\text { Discounted } \\
\text { cash flow }\end{array}$ \\
\hline 1 & 2 & 3 & 4 & 5 & 6 & 7 & 8 \\
\hline 2019 & -692530 & 1 & -692530 & 1 & -692530 & 1 & -692530 \\
\hline 2020 & 31650,6 & 0,926 & 29308 & 0,909 & 28770 & 0,893 & 28264 \\
\hline 2021 & 33866,1 & 0,858 & 29057 & 0,751 & 25433 & 0,797 & 26991 \\
\hline 2022 & 36236,8 & 0,794 & 28772 & 0,683 & 24750 & 0,712 & 25801 \\
\hline 2023 & 38773,3 & 0,735 & 28498 & 0,621 & 24078 & 0,6355 & 24640 \\
\hline 2024 & 41487,5 & 0,681 & 28253 & 0,564 & 23399 & 0,567 & 23523 \\
\hline 2025 & 44391,6 & 0,663 & 29432 & 0,318 & 14117 & 0,5066 & 22489 \\
\hline 2026 & 47499 & 0,583 & 27692 & 0,1797 & 8536 & 0,453 & 21517 \\
\hline 2027 & 50823,9 & 0,54 & 27445 & 0,424 & 21549 & 0,404 & 20533 \\
\hline 2028 & 54381,6 & 0,5 & 27191 & 0,3855 & 20964 & 0,361 & 19632 \\
\hline 2029 & 58188,3 & 0,463 & 26941 & 0,35 & 20376 & 0,322 & 18737 \\
\hline 2030 & 62261,5 & 0,429 & 26710 & 0,319 & 19861 & 0,287 & 17869 \\
\hline 2031 & 66619,8 & 0,397 & 26448 & 0,29 & 19320 & 0,257 & 17121 \\
\hline 2032 & 71283,2 & 0,368 & 26232 & 0,263 & 18747 & 0,229 & 16324 \\
\hline 2033 & 76273 & 0,34 & 25933 & 0,239 & 18229 & 0,205 & 15636 \\
\hline 2034 & 81612,2 & 0,315 & 25708 & 0,2176 & 17759 & 0,183 & 14935 \\
\hline 2035 & 87325 & 0,292 & 25499 & 0,198 & 17290 & 0,163 & 14234 \\
\hline 2036 & 93437,8 & 0,27 & 25228 & 0,18 & 16819 & 0,146 & 13642 \\
\hline 2037 & 99978,4 & 0,25 & 24995 & 0,1635 & 16346 & 0,13 & 12997 \\
\hline 2038 & 106977 & 0,232 & 24819 & 0,149 & 15940 & 0,116 & 12409 \\
\hline 2039 & 114465 & 0,215 & 24610 & 0,135 & 15453 & 0,104 & 11904 \\
\hline 2040 & 122478 & 0,198 & 24251 & 0,1286 & 15751 & 0,09 & 11023 \\
\hline 2041 & 131051 & 0,184 & 24113 & 0,112 & 14678 & 0,083 & 10877 \\
\hline 2042 & 140225 & 0,17 & 23838 & 0,109 & 15285 & 0,074 & 10377 \\
\hline 2043 & 150041 & 0,158 & 23706 & 0,1015 & 15229 & 0,066 & 9903 \\
\hline Total & & & -57850 & & -243861 & & -271152 \\
\hline & & & & & & &
\end{tabular}

Since the net discounted flow is positive at the rate of $6 \%$, the payback period of the project can be determined only at this rate:

$\mathrm{T}_{\mathrm{pb}}=22-((-24532) /(37219+24532))=22,8$ years

According to calculations, the sum of discounted cash flow elements changes sign from negative to positive between 22 and 23 years of the investment period. The resulting payback period is 22.8 years.

Then, one needs to determine the internal rate of return:

$\mathrm{IRR}=6+((91159 *(8-6)) /(91159+57850))=6,2 \%$ 
The IRR indicator showed that the total discounted cash flow became negative at a discount rate of $6.2 \%$.

Since the net present value is negative when the discount rate is above $6 \%$, the rest of the indicators (payback period, internal rate of return) cannot be calculated.

Project performance indicators are summarized in Table 5.

Table 5 Investment project's performance indicators for the construction and operation of a floating solar power plant

\begin{tabular}{|l|l|c|c|c|c|}
\hline \multirow{2}{*}{$\begin{array}{l}\text { Measurement } \\
\text { units }\end{array}$} & \multicolumn{4}{|c|}{ Discount rate, \% } \\
\cline { 3 - 6 } & 6 & 8 & 10 & 12 \\
\hline Net present value & Thousand rubles & 91159 & -57850 & -243861 & -271152 \\
\hline Payback period & years & 22,8 & & & \\
\hline Internal rate of return & $\%$ & 6,2 & & & \\
\hline Profitability index & $\begin{array}{c}\text { The proportion } \\
\text { of units }\end{array}$ & 1,13 & 0,92 & 0,59 & 0,62 \\
\hline
\end{tabular}

The discount rate of $6 \%$ was taken as the base one. In this case, the net discounted income will be 91,159 thousand rubles. The project will pay off in 22.8 years. A further increase in the discount rate will lead to negative net discounted income; the payback period, in this case, is longer than the project implementation period ( 25 years). The internal discount rate cannot be calculated, since it is higher than the pledged discount (8, 10 , and $12 \%$, respectively).

\section{Conclusion}

Having analyzed data, the following conclusions can be drawn:

- the development of the electric power industry based on renewable energy sources in the Russian Federation is at an extremely low level, the entire volume of generated electricity is only about $0.2 \%$ of the total volume, while the global average is about $8 \%$;

- further development of energy using alternative sources should be based on innovative ways of developing such facilities. One of such areas is the creation of floating power plants, which can significantly reduce not only the cost of electricity but also ensure environmental safety;

- the modeling has shown that using floating power plants is one of the promising areas for the development of alternative electric power, due to the cost reduction of generated electricity. Investment projects in this area are profitable that allow using the possibilities of attracting not only public investments but also private financing, i.e. applying all the possibilities of the public-private partnership mechanism.

\section{References}

1. Bataev, A. (2020). Performance evaluation of cloud services for russian companies. Paper presented at the Conference of Open Innovation Association, FRUCT, , 2020April 46-51. doi:10.23919/FRUCT48808.2020.9087427

2. Bataev, A. V., Dedyukhina, N., \& Nasrutdinov, M. N. (2020). Innovations in the financial sphere: Performance evaluation of introducing service robots with artificial intelligence. Paper presented at the ICITM 2020 - 2020 9th International Conference on Industrial Technology and Management, 256-260. doi:10.1109/ICITM48982.2020.9080379

3. Afonichkina, E., Kobylko, A., Kobylko, E., Voronova, L., \& Safonova, A. S. (2020). Analysis of sustainable development of the arctic territories of the russian federation. 
Paper presented at the IOP Conference Series: Earth and Environmental Science, , 539(1) doi:10.1088/1755-1315/539/1/012103

4. Elgamal, M., Korovkin, N., Elmitwally, A., \& Chen, Z. (2020). Robust multi-agent system for efficient online energy management and security enforcement in a gridconnected microgrid with hybrid resources. IET Generation, Transmission and Distribution, 14(9), 1726-1737. doi:10.1049/iet-gtd.2019.1284

5. Dyatlov, S. A., Didenko, N. I., Ivanova, E. A., Soshneva, E. B., \& Kulik, S. V. (2020). Prospects for alternative energy sources in global energy sector. Paper presented at the IOP Conference Series: Earth and Environmental Science, , 434(1) doi:10.1088/1755-1315/434/1/012014

6. Karminsky, A. M., Grishunin, S., Dyachkova, N., \& Bisenov, M. (2020). The comparison of empirical methods for modeling credit ratings of industrial companies from BRICS countries. Eurasian Economic Review, 10(2), 333-348. doi:10.1007/s40822-019-00130-4

7. Antipov, S. K., Didenko, N. I., Lobatyuk, V. V., \& Sosnina, M. N. (2020). Comparing models of sustainable development for the arctic region of the russian federation. Paper presented at the IOP Conference Series: Earth and Environmental Science, , 539(1) doi:10.1088/1755-1315/539/1/012102

8. Vasilyeva, E., \& Krupnov, Y. (2020). Development of the methodological approach to the comprehensive assessment of the innovative project effectiveness. Paper presented at the E3S Web of Conferences, , 164 doi:10.1051/e3sconf/202016410037

9. Bozhuk, S. G., Maslova, T. D., Pletneva, N. A., \& Evdokimov, K. V. (2019). Improvement of the consumers' satisfaction research technology in the digital environment. Paper presented at the IOP Conference Series: Materials Science and Engineering, , 666(1) doi:10.1088/1757-899X/666/1/012055

10. Cherenkov, V. I., Skripnuk, D. F., Tanichev, A. V., \& Safonova, A. S. (2020). A conceptual framework of logistics infrastructure for implementing the circular economy model in the russian arctic. Paper presented at the IOP Conference Series: Earth and Environmental Science, , 539(1) doi:10.1088/1755-1315/539/1/012077

11. Demidov, V., Mokhorov, D., \& Mokhorova, A. (2020). Cooperation of russia with arctic nations in the field of legal regulation of the use of northern territories. Paper presented at the IOP Conference Series: Earth and Environmental Science, , 539(1) doi:10.1088/1755-1315/539/1/012051

12. Ivanov, D., Kalinin, M., Krundyshev, V., \& Orel, E. (2020). Automatic security management of smart infrastructures using attack graph and risk analysis. Paper presented at the Proceedings of the World Conference on Smart Trends in Systems, Security and Sustainability, WS4 2020, 295-300. doi:10.1109/WorldS450073.2020.9210410

13. Didenko, N. (2020). Modeling the global nickel market with a triangular simultaneous equations model. International Journal of Systems Assurance Engineering and Management, 11, 119-129. doi:10.1007/s13198-019-00936-0

14. Gamayunova, O., Musorina, T., Petrichenko, M., \& Goremikins, V. (2020). Warming of panel houses in various climatic zones doi:10.1007/978-3-030-42351-3_22

15. Grebnev, Y., Moskalev, A., Vershkov, A., \& Gazizulina, A. (2020). The practice of connectionist model for predicting forest fires in the arctic zones of the krasnoyarsk territory. International Journal of Systems Assurance Engineering and Management, 11 doi:10.1007/s13198-019-00786-w

16. Mikheev, P., Okorokov, R., Sidorenko, G., \& Timofeeva, A. (2020). Determination of energy costs of wind farms at all life cycle stages doi:10.1007/978-3-030-19756-8_22 